Vol. 20(2011): 29-41.

\title{
Emerging virus and viroid pathogen species identified for the first time in horticultural plants in Finland in 1997-2010
}

\author{
Anne Lemmetty ${ }^{1}$, Jaana Laamanen ${ }^{2}$, Mirkka Soukainen ${ }^{3}$ and Jukka Tegel ${ }^{3}$ \\ ${ }^{1}$ MTT Agrifood Research Finland, Plant Production Research, FI-31600 Jokioinen, Finland \\ ${ }^{2}$ MTT Agrifood Research Finland, Plant Production Research, Antinniementie 1, FI-41330 Vihtavuori, Finland \\ ${ }^{3}$ Finnish Food Safety Authority Evira/ Plant Quarantine Laboratory, Mustialankatu 3, FI-00790 Helsinki, Finland \\ e-mail: anne.lemmetty@mtt.fi
}

Expansion and intensification of global trade in horticultural plants has increased the risk of spread of new alien pathogen species in the European Union (EU). Alien species of pathogenic viruses and viroids in horticultural plants have been introduced into Finland in infected plant material (plants, seedlings, cuttings, tubers, seeds). By 1997, about 30 virus species of horticultural plants had been detected in Finland. We aimed at compiling emerging new virus and viroid records during 1997-2010. Eight new viruses belonging to tospo-, potex-, poty-, tymo-, ilar- and allexiviruses were detected in horticultural plants: four occurred in greenhouse crops, two in vegetables and two in garden ornamentals outdoors. Five new findings of viroids were made in ornamental and vegetable greenhouse crops during 2008-2009. More rapid and accurate diagnostic methods have contributed to identifying new alien pathogens. Global trade seems to be the main reason for the introduction of the newest virus and viroid pathogens into Finland.

Key-words: allexi-, ilar-, potex-, poty-, tospo- and tymovirus, viroid, ELISA, PCR, sequencing 


\section{AGRICULTURAL AND FOOD SCIENCE}

Lemmetty, A. et al. Emerging virus and viroid pathogen species

\section{Introduction}

Expansion and intensification of global trade in horticultural plants has increased the risk of new alien species invasion in the EU. Alien species are defined as organisms that are non-indigenous to an area and that have entered an area by human agency. Plant material is more frequently propagated and grown in different countries from which it is imported. Infected plants are exchanged between different continents through trade flows (Brasier 2005). The large volume of ornamentals traded around the world cannot adequately be inspected or monitored even though more rapid and accurate diagnostics methods for plant pathogens have been developed (Mumford et al. 2006, Lopez et al. 2008). As a consequence, plant pathogens are spreading faster than previously and species new to Europe and Finland are becoming invasive. For example, economically important whitefly-transmitted virus of tomato, Tomato yellow leaf curl virus, has spread in the Mediterranean countries (Moriones and Navas-Castillo 2000) and was already detected in the Netherlands in 2007 (Botermans et al. 2009). The global spread of the polyphagous Bemisia tabaci on traded plant material is a major factor in the increase in whitefly-transmitted diseases worldwide (Jones 2003). In virus detection, especially for latent virus infections, the lack of validated sampling protocols, uneven distribution and low virus titres can cause problems. Alien species can remain undetected for long periods and become a problem with a change in climate favouring their survival and dispersal.

Alien virus species in horticultural plants have been introduced into Finland in imported infected plant material (plants, cuttings, seedlings, tubers, seeds). Some cultivated woody horticultural plants, for example berry plants and ornamentals, were imported hundreds of years ago. Larsson and Lokonen (1984) mentioned nurseries in Russia, Germany, Sweden and Norway from which plant material had been imported into Finland in the 17th and 18th centuries. Many woody horticultural plants have been cultivated for a long time in areas far from their centres of domestication and for this reason it is often difficult to know whether the viruses found evolved locally or were introduced (Jones 2009).

The presence of many of the most recently detected viruses and all viroids has been confirmed using PCR methods. New nucleic acid based detection methods have improved the identification of alien plant viruses and even made it possible to find new causal agents (Lemmetty et al. 1997). Identification of an agent has in turn improved diagnosis. Numerous nucleic acid sequences of plant viruses have been published and sequence comparisons have opened up new possibilities for documenting virus taxonomy and diversity.

Identification of a new virus pathogen can be difficult although the detection methods have improved. Symptoms can also be misinterpreted. For example, the virus may remain undetected if it represents new selectable plant characters in a breeding programme. The classic example is the Tulip breaking virus that became much sought after. Bos (1970) described how fortunes were paid for the bulb of nicely broken tulips in 1634-1637. Later it was established that the virus reduced plant size and bulb yield. Hostas are popular perennial garden plants and new varieties are in high demand. Hosta $\mathrm{X}$ virus (Table 1), an easily transmitted potexvirus, was spread globally with a new variety before the causal agent for the leaf coloration was established (Currier and Lockhart 1996). Virus symptoms can also resemble phytotoxic responses to pesticide sprays or other chemicals, as in Euphorbia spp.

Virus and viroid diseases are a potential threat to all crops, but especially to high value horticultural crops in Finland. In 2008, the total area devoted to horticulture was about 15300 hectares. The production area in the open was 14900 hectares, of which vegetable production was the most significant sector, with a 55\% share. The share of berry production was $41 \%$ and that of fruit production about $4 \%$. The total greenhouse production area was about 400 hectares, comprising vegetable production, with a $62 \%$ share and ornamental production with a $38 \%$ share (Niemi and Ahlsted 2009).

In Finland, fungi and viruses have been common plant pathogens in horticultural plants for decades. Tapio et al. (1997) published a list of viruses identified in agricultural and horticultural crops in 
Vol. 20(2011): 29-41.

Table 1. Identified viruses and viroids emerging in horticultural crops in Finland in 1997-2010

\begin{tabular}{|c|c|c|c|c|c|c|}
\hline $\begin{array}{l}\text { Virus or viroid } \\
\text { species }\end{array}$ & $\begin{array}{l}\text { Taxonomic } \\
\text { position }\end{array}$ & $\begin{array}{l}\text { Recorded host } \\
\text { species }\end{array}$ & Transmission & $\begin{array}{l}\text { Detection } \\
\text { method }^{\mathrm{a}}\end{array}$ & $\begin{array}{l}\text { Year of first } \\
\text { detection }\end{array}$ & $\begin{array}{l}\text { References for } \\
\text { first detections }\end{array}$ \\
\hline $\begin{array}{l}\text { Poinsettia } \\
\text { mosaic virus }\end{array}$ & $\begin{array}{l}\text { Tymovirus; } \\
\text { Tymoviridae }\end{array}$ & $\begin{array}{l}\text { Euphorbia } \\
\text { pulcherrima }\end{array}$ & cuttings & ELISA, EM & 1993 & $\begin{array}{l}\text { Lemmetty \& } \\
\text { Tegel } 1993^{1}\end{array}$ \\
\hline $\begin{array}{l}\text { Impatiens } \\
\text { necrotic spot } \\
\text { virus }\end{array}$ & $\begin{array}{l}\text { Tospovirus; } \\
\text { Bunyaviridae }\end{array}$ & Begonia sp. & cuttings, thrips & ELISA & 1998 & $\begin{array}{l}\text { Tegel \& } \\
\text { Lemmetty } 1998^{2}\end{array}$ \\
\hline $\begin{array}{l}\text { Pepino mosaic } \\
\text { virus }\end{array}$ & $\begin{array}{l}\text { Potexvirus; } \\
\text { Alphaflexiviridae }\end{array}$ & $\begin{array}{l}\text { Solanum } \\
\text { lycopersicum }\end{array}$ & seeds, tomatoes & EM, ELISA & 2001 & KTTK $2001^{3}$ \\
\hline $\begin{array}{l}\text { Apple mosaic } \\
\text { virus }\end{array}$ & $\begin{array}{l}\text { Ilarvirus; } \\
\text { Bromoviridae }\end{array}$ & Humulus lupulus & plants & ELISA, PCR & 2005 & MTT $2005^{4}$ \\
\hline Hosta virus $X$ & $\begin{array}{l}\text { Potexvirus; } \\
\text { Alphaflexiviridae }\end{array}$ & Hosta sp. & plants & ELISA & 2008 & Evira $2008^{5}$ \\
\hline Garlic virus $B$ & $\begin{array}{l}\text { Allexivirus; } \\
\text { Alphaflexiviridae }\end{array}$ & Allium sativum & mites & ELISA & 2009 & MTT $2009^{6}$ \\
\hline Garlic virus $C$ & $\begin{array}{l}\text { Allexivirus; } \\
\text { Alphaflexiviridae }\end{array}$ & Allium sativum & mites & ELISA & 2009 & MTT $2009^{6}$ \\
\hline $\begin{array}{l}\text { Zucchini yellow } \\
\text { mosaic virus }\end{array}$ & $\begin{array}{l}\text { Potyvirus; } \\
\text { Potyviridae }\end{array}$ & Cucumis sativus & aphids & ELISA & 2010 & Evira $2010^{7}$ \\
\hline $\begin{array}{l}\text { Potato spindle } \\
\text { tuber viroid }\end{array}$ & Pospiviroid & $\begin{array}{l}\text { Brugmansia sp. } \\
\text { Chrysanthemum sp. } \\
\text { Solanum jasminoides } \\
\text { S. pseudocapsicum }\end{array}$ & plants & $\begin{array}{l}\text { RT-PCR + } \\
\text { sequencing }\end{array}$ & 2008 & Evira $2008^{5}$ \\
\hline $\begin{array}{l}\text { Tomato apical } \\
\text { stunt viroid }\end{array}$ & Pospiviroid & $\begin{array}{l}\text { S. jasminoides } \\
\text { S. rantonnetii }\end{array}$ & plants & $\begin{array}{l}\text { RT-PCR + } \\
\text { sequencing }\end{array}$ & 2008 & Evira $2008^{5}$ \\
\hline $\begin{array}{l}\text { Chrysanthemum } \\
\text { stunt viroid }\end{array}$ & Pospiviroid & Petunia sp. & plants & $\begin{array}{l}\text { RT-PCR + } \\
\text { sequencing }\end{array}$ & 2009 & Evira $2009^{8}$ \\
\hline $\begin{array}{l}\text { Tomato chlorot- } \\
\text { ic dwarf viroid }\end{array}$ & Pospiviroid & Petuniasp. & plants & $\begin{array}{l}\text { RT-PCR + } \\
\text { sequencing }\end{array}$ & 2009 & Evira $2009^{8}$ \\
\hline Hop stunt viroid & Hostuviroid & Cucumis sativus & not known & $\begin{array}{l}\text { r-PAGE, } \\
\text { RT-PCR + } \\
\text { sequencing }\end{array}$ & 2009 & Evira $2009^{8}$ \\
\hline
\end{tabular}

${ }^{a}$ ELISA=enzyme linked immunosorbent assay, $\mathrm{EM}=$ electron microscopy, $\mathrm{PCR}=$ polymerase chain reaction, $\mathrm{RT}$-PCR=reverse transcription PCR, r-PAGE=r-polyacrylamidegelelectrophoresis

${ }^{1}$ Lemmetty, A. \& Tegel, J. 1993. Virus oireillut joulutähdissä. Puutarha-Uutiset 45, 51-52: 10. (in Finnish)

${ }^{2}$ Tegel, J. \& Lemmetty, A. 1998. Palsamin kuoliolaikkuvirus löydetty begoniasta. Puutarha \& Kauppa 17/98 : 17.(In Finnish)

${ }^{3}$ KTTK 2001. Toimintakertomus 2001. Kasvintuotannon tarkastuskeskus, kasvintarkastus. Dnro 2/023/2002. (In Finnish)

${ }^{4}$ MTT 2005. Laukaa 1984-2010. Varmennetun taimituotannon kasvirekisteri: kasvintuhoojat. (In Finnish)

${ }^{5}$ Evira 2008. Kasvinterveysyksikön valvontaraportti 2008. Dnro 2196/0411/2009. (In Finnish)

${ }^{6}$ MTT 2009. Laukaa 1984-2010. Varmennetun taimituotannon kasvirekisteri: kasvintuhoojat. (In Finnish)

${ }^{7}$ Evira 2010. Notification of outbreak of Zucchini yellow mosaic virus in Finland. Pest report. Dnro 5264/0610/2010

${ }^{8}$ Evira 2009.Kasvinterveysyksikön valvontaraportti. Dnro 1480/0411/2010. (In Finnish) 


\section{AGRICULTURAL AND FOOD SCIENCE}

Lemmetty, A. et al. Emerging virus and viroid pathogen species

Finland. The list included 44 viruses of which approximately 30 were identified from vegetables, berries, fruit trees and ornamentals. The viruses were identified on the basis of symptoms in test plant species by using serological methods and through studying the morphology of virus particles under the electron microscope. In the earliest virus report, Rainio (1941) described virus diseases in cucumber and the latest record is associated with isolation of a new virus from blackcurrant (Lemmetty et al. 1997).

In this paper, we aimed at compiling records of new identified viruses and viroids (Table 1) found after the review by Tapio et al. (1997) during the past 15 years. The records are based on lists maintained by organizations such as the Finnish Food Safety Authority Evira (Evira) and MTT Agrifood Research Finland. Most of the expert-knowledge based first records of pathogen detection have been published in Finnish in official documents by Evira or in reports by Evira and MTT to inspectors and advisors, and in newspapers for growers. The primary focus is on new viruses and viroids introduced into Finland and detected during the past 15 years, but we represent some records of new virus detection with nucleic acid based or serological methods for causal agents of diseases recorded earlier.

Four of the eight emerging new viruses identified occurred in greenhouse crops, two in vegetables and two in garden ornamentals outdoors. Five new findings of viroids were made in ornamental and vegetable greenhouse crops during 2008-2009.

\section{Viruses from tropical regions survive in the greenhouse}

Some viruses that were earlier considered a threat in tropical and subtropical regions have become a potential threat at northern latitudes in Finland where greenhouse cultivated tomatoes, cucumbers, lettuce and several ornamentals can be severely affected. There are viruses which are important only or mainly for the ornamental crop itself like Poinsettia mosaic virus (PnMV) on poinsettia (Euphorbia pulcherrima Willd. ex Klotzsch). These viruses have restricted host range and represent little danger for other crops. At the other extreme there are viruses that have a wide host range and are transmitted by vectors and are danger for other crops.

\section{Poinsettia mosaic virus}

Poinsettia mosaic virus, a RNA-containing tymolike isometric virus, was first reported in E. pulcherrima in USA by Fulton and Fulton (1980). The virus has been detected commonly in commercially grown poinsettias in USA (Fulton and Fulton 1980), in Germany (Koenig and Lesemann 1980) and in Canada (Chico 1983). E. pulcherrima and E. fulgens are the only natural hosts known (Paludan and Begtrup 1986). The virus is sap-transmissible but no vector is known. Symptoms of this virus are distortion of leaves and bracts and some bracts may fail to colour normally. When the symptoms of misshapen and narrow upper leaves of poinsettias first occurred in Finland the cause was put down to spraying damage. However, Poinsettia mosaic virus was isolated from symptomatic plants by sap-transmission to Nicotiana benthamiana and spherical virus particles approximately $29 \mathrm{~nm}$ in diameter were observed in negatively stained samples by electron microscopy. The virus was also confirmed with ELISA using commercial antiserum (DSMZ, Braunschweig, Germany) (Table 1). After the first detection in Finland Poinsettia mosaic virus symptoms have been observed occasionally in poinsettia plants produced from imported cuttings for Christmas pot plants and during some years the symptoms have been particularly severe.

\section{Impatiens necrotic spot virus}

A globally significant new virus disease problem developed in the greenhouse floriculture industry when Impatiens necrotic spot (INSV), a RNA- 
Vol. 20(2011): 29-41.

containing tospovirus (Bunyaviridae) spread worldwide through vegetative propagation of infected plant material (Daughtrey et al. 1997, Moriones et al. 1998) and by the feeding activity of certain thrips species, especially western flower thrips (Frankliniella occidentalis Pergande; Thysanoptera (Best 1968, Jones 2005). INSV was first reported in New Guinea impatiens (Impatiens sp.) in the USA (Law and Moyer 1990) and by 1992 it was established as being a separate virus from Tomato spotted wilt virus (TSWV) (de Avila et al. 1992). The European greenhouse industry had its first outbreaks of tospoviruses during the late 1980s with the importation of the western flower thrips and TSWV. Growers in northern climates introduce thrips (e.g. F. occidentalis) when cuttings and flower crops are brought into the greenhouse. Without the grower's knowledge, tospoviruses are easily maintained in a greenhouse in the weeds, which can be reservoirs of INSV and TSWV regardless of whether they show symptoms or not. In a field survey in Japan INSV was regularly detected in Stellaria media (Okuda 2010), which is a common weed in greenhouses. TSWV and INSV cause a broad range of symptoms on many plants. The possible symptoms include stunting, necrotic spotting, chlorotic spotting, areas of black or brown stem necrosis, ring spots, mosaic, line patterns and vein necrosis. Symptoms vary according to the virus, host, cultivar, time of year, and environmental factors (German et al. 1992).

The first TSWV occurrence in Finland was in greenhouse tomatoes in 1989 (Lemmetty and Lindqvist 1993) and could be traced back to the importation of chrysanthemum cuttings. The grower cultivated both tomatoes and chrysanthemums, and thrips transmitted the new virus from ornamentals to the tomatoes. Nine years later, in 1998, INSV was detected for the first time in imported ornamentals, Begonia Elatior-hybr. and Impatiens walleriana in Finland (Table 1). The detection was based on symptoms in a host plant, a mechanical inoculation to indicator plants and serology with ELISA (Loewe Biochemica, GmbH, Germany). Later INSV has been detected occasionally from different ornamentals e.g. I. walleriana, Streptocarpus sp. (KTTK 2002), Begonia sp., Lobelia sp., Chrysanthemum sp., Schlumbergera sp., Ka- lanchoe sp. (KTTK 2003), Dahlia sp., I. hawkeri, Saintpaulia ionantha (KTTK 2004), Cyclamen sp. (KTTK 2005), Senecio cineraria, Pericallis sp. (Evira 2007). INSV and TSWV both have quarantine status in Finland and have been eradicated from greenhouses. Evira inspects and controls the eradication of quarantine pests. INSV and TSWV have been eradicated in greenhouse crops in Finland for the present, but globally they still increase their distribution and host range.

\section{Pepino mosaic virus}

Most intercepted alien virus pathogens, especially quarantine viruses detected in greenhouse crops, have not become established because the host or consignment has been destroyed. This happened with Pepino mosaic virus (PepMV), which is a readily contact-transmissible RNA-containing potexvirus. PepMV was first found infecting pepino (Solanum muricatum L'Hér.ex Aiton) in 1974 in Peru (Jones et al. 1980). PepMV natural host range is mainly restricted to the Solanaceae. It affects tomatoes, but several weed hosts were also found to be infected with PepMV (Jones et al. 1980). It appeared to infect tomatoes in the Netherlands in 1999 (van der Vlugt et al. 2000) and then spread rapidly to several European countries (Mumford and Metcalfe 2001, Cotillion et al. 2002). PepMV was first detected in tomato plants in Finland in spring 2001 (Table 1). Symptomatic tomato plants (Fig. 1) were observed by a horticultural adviser in a tomato greenhouse in Ostrobothnia. The leaf samples were examined by electron microscopy and filamentous particles of approximately $500 \mathrm{~nm}$ in negatively stained samples suggested that PepMV could be the causal agent of the symptoms. The virus detection was confirmed by ELISA using a commercial antiserum (Loewe Biochemica, GmbH, Germany).

Later in 2001 Evira, formerly the Plant Production Inspection Center, conducted a survey of PepMV with reference to Commission Decision 2001/536/EC. Inspections were carried out for domestic tomato plant and fruit production in greenhouses. In the survey 481 greenhouses, of which 


\section{AGRICULTURAL AND FOOD SCIENCE}

Lemmetty, A. et al. Emerging virus and viroid pathogen species

466 were tomato fruit producers and 15 tomato plant producers, were inspected visually. Of these inspections, 266 samples, mainly of leaves, were collected from 69 producers and tested by ELISA using a commercial antiserum. The virus was found in 6 premises, all producing tomato fruits (Table 1). The virus has been successfully eradicated in all infested greenhouses. During the same year PepMV infected tomatoes were detected among imported tomato fruits originating from other European countries. From total of 95 inspected lots, 8 were PepMV infected. The tomatoes were transported from Spain and the Netherlands.

In spring 2002, the virus was detected once again in tomato fruits imported into Finland. However, greenhouse growers had been informed about the highly contagious PepMV and they were conscious of the risk that tomato fruit harvested from infected plants contain high concentrations of the virus and the virus can be spread over long distances (van der Vlugt 2009). PepMV is present in at least 15 member states in the EU and the virus causes significant problems with different isolates and strains and mixed infections with other viruses e.g. Tomato torrado virus (ToTV) (Hanssen et al. 2010a). Strict hygiene measures in greenhouses and constant monitoring have contributed to the situation that to date PepMV is not present in greenhouses in Finland. The latest reports show that the virus can be seed-transmitted (Hanssen et al. 2010b). This

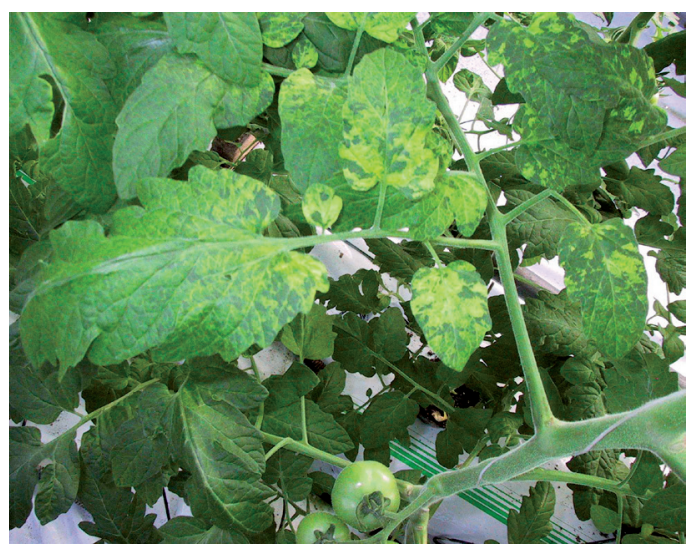

Fig. 1. Yellow leaf mosaic symptoms on tomato have been associated with Pepino mosaic virus. Photo: Jukka Tegel. result confirms earlier assumptions that the sudden spread of the virus from South America to Europe might include seed transmission as international seed companies use South America to propagate seed crops for sale and there is increased speed and volume of international trade in tomato seeds and fruits (Verhoeven et al. 2003, Mumford and Jones 2005). Bumble bees used as pollinators in greenhouses were also shown to transmit the virus (Shipp et al. 2008).

\section{Zucchini yellow mosaic virus}

The latest exotic virus detected appeared in summer 2010 in a greenhouse in southeastern Finland where cucumbers (Cucumis sativus L.) were cultivated. The grower observed uncommon leaf symptoms (Fig. 2 ) and bushy like tops on a few cucumber plants in an approximately three meter section of a row. The conspicuous symptoms occurred in the young cucumber fruits, which were curved and hooked. There were no traces of substantial populations of thrips, aphids or whiteflies. These peculiar symptoms in cucumber and the filamentous particles of approximately $750 \mathrm{~nm}$ in electron microscopy samples suggested that this was not a common cucumber virus in Finland and no clear clue was evidence regarding vectors was available from the grower.

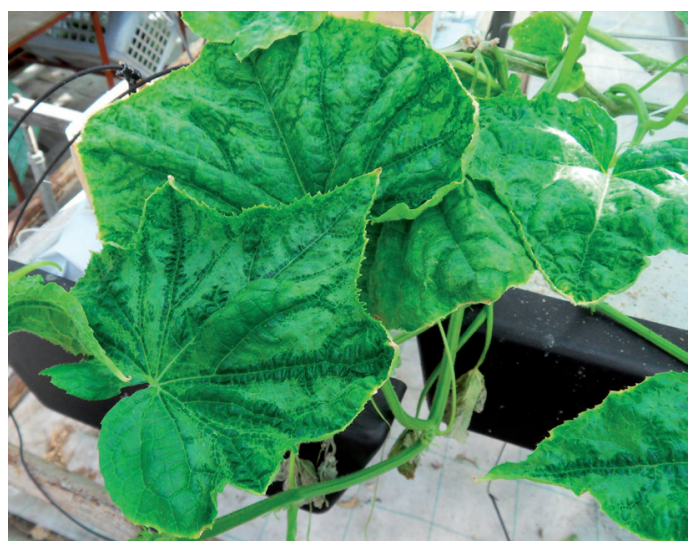

Fig. 2. Deformation of leaves on Zucchini yellow mosaic virus infected cucumber. Photo: Salla Hannunen. 
Vol. 20(2011): 29-41.

The virus was characterised in The Netherlands as Zucchini yellow mosaic virus (ZYMV) (Table 1). The origin and the transmission pathway of the virus to a Finnish cucumber greenhouse remain unknown.

ZYMV is a RNA-containing potyvirus, which is transmitted in a non-persistent manner by many aphids (Simmons et al. 2008). ZYMV was first reported in Cucurbita pepo in Italy by Lisa et al. 1981). Later the virus was reported to cause epidemics on Cucurbitaceae crops in Italy, France, UK, Australia, Egypt, USA, and also in some African and Asian countries (Desbiez and Lecoq 1997). In 1983 and $1987 / 88$ two localized but damaging epidemics developed in the Netherlands (Schrijnwerkers et al. 1991). Aphid transmission is undoubtedly the main route, but seed transmission has also been proposed (Schrijnwerkers et al. 1991).

\section{New viruses in Finland identified from ornamentals and outdoor vegetables}

Landscaping plants are very popular in Finland. One reason for debilitated hosta plants turned out to be a contact transmissible potexvirus. Nowadays hops in Finland are mainly grown in gardens as landscaping plants and their decorative value is decreased by virus infections. Furthermore, because new emerging viruses arrive with transported plant material from Europe, outdoor crops are susceptible to vector transmitted viruses that established earlier in Finland. For example, garlic viruses usually occurred in mixed infections with several viruses from different taxonomic group

\section{Hosta virus X}

Hostas (Hosta spp. Tratt.) are well-liked landscape perennials that have recently become popular in public areas in Finland. In 1996, a new virus of hostas was described in the USA. Virus-like disorders were observed in nursery production and in naturally infected plants from different parts of midwestern USA. The new virus was a RNA-containing potexvirus, named Hosta virus X (HVX). The virus causes symptoms including unusual mottling, chlorotic spotting and colour mutation, but it can also be latent. HVX spreads by vegetative propagation and mechanical transmission. On susceptible cultivars, HVX can become a serious and sometimes destructive disease (Currier and Lockhart 1996).

The first detection of HVX in Finland was made in 2008 when Evira found the virus in hostas transported from the Netherlands to Finland (Table 1). Subsequently, 427 hosta samples were tested for HVX and the virus was detected in 42. Among the infected plant lots, 38 were from 10 nurseries and 5 from retail garden centres. Most of the HVXpositive lots originated from the Netherlands, but 3 lots were of Finnish origin. Many nurseries buy small hosta plants from other EU countries for further cultivation and to supplement their own collections. Marketing of infected plant lots has been prohibited, but there is a risk that HVX will establish in Finnish nursery production and the virus will spread to Finnish landscaping areas.

\section{Apple mosaic virus}

Apple mosaic virus (ApMV) is a RNA-containing ilarvirus and has a wide host range in the Rosaceae (Brunt et al. 1996). ApMV was first reported in Malus domestica by Bradford and Joley (1933) in the USA. Two serotypes of ApMV are found infecting hops (Humulus lupulus L.), ApMV-H (hop) and ApMV-I (intermediate) (Crowle et al. 2003). In hops ApMV is transmitted in gardens by mechanical inoculation, plant-to-plant contact, pruning and other contacts during agronomic practices (Pethybridge et al. 2002a). ApMV in hop can cause significant losses in cone yield and decreased levels of brewing organic acids. Virus infections overall may cause problems in plant propagation, including death of softwood cuttings in hops (Pethybridge et al. 2002b). Leaf symptoms in hops are chlorotic, 


\section{AGRICULTURAL AND FOOD SCIENCE}

Lemmetty, A. et al. Emerging virus and viroid pathogen species

later necrotic ringspots and oak-leaf like patterns (Pethybridge et al. 2008). Geographical distribution of ApMV is probably worldwide (Brunt et al. 1996) and in hops ApMV is reported at least from Australia, Germany, New Zealand, the UK and the USA (Pethybridge et al. 2008).

During 2005-2006 ApMV was found from 4 of 11 Finnish hop clones selected for long-term conservation by an MTT working group for the Finnish National Programme for Plant Genetic Resources. Apple mosaic virus screening with ELISA (Loewe Biochemica, GmbH, Germany) showed higher absorbance values in samples of hop plants and the results were confirmed with PCR using primers published for Apple mosaic virus (Menzel et al. 2002). Apple mosaic virus was earlier detected based on symptoms in apple trees in Finland (Bremer 1985), but this was the first time it was detected by ELISA and PCR methods in hops in Finland.

\section{Garlic virus $B$ and $C$}

Six different RNA-containing allexiviruses have been found; GarV-A (Sumi et al. 1999), GarV-B (Sumi et al. 1993), GarV-C (Sumi et al. 1999), GarVD (Sumi et al. 1993), GarV-E (Chen et al. 2001) and GarV-X (Song et al. 1997). Allexiviruses have been detected at least from Japan (Sumi et al. 1993), Argentina (Perotto et al. 2010), China (Chen et al. 2001) and Korea (Koo et al. 2002). Allexiviruses can cause significant losses in crop yield (Carfune et al. 2006). The viruses are transmitted by mites (Aceria tulipae) (Kang et al. 2007). The mite was detected in Finland already in the 1940s in onion (Allium cepa L.) leaves and was probably already widely distributed in the country (Liro \& Roivanen 1951). No indexing of the mites has been done subsequently in Finland.

Garlic virus $B$ (GarV-B) and Garlic virus $C$ (GarV-C) (Table 1.) were found in Finland in 2009 using ELISA to test a farmer clone with strong symptoms and an asymptomatic old Finnish garlic cultivar 'Heimala'. Antisera against GarV-B and GarV-C were obtained from DSMZ, Braunsch- weig, Germany. The farmer clone was imported from the Canary Islands into Finland by a tourist at the end of 1980. The clone was cultivated in southwest Finland until the beginning of 2000, when virus symptoms became evident following a substantial aphid invasion that rendered the clone useless. The clone was infected with GarV-B and in addition three aphid transmissible viruses; Onion yellow dwarf virus (OYDV), Shallot latent virus (SLV) and Leek yellow stripe virus (LYSV). Cultivar 'Heimala' was infected by GarV-B, GarV-C and OYDV.

\section{Establishment of alien virus species}

Woody horticultural plants outdoors easily act as nets for vector transmitting viruses. An initial virus introduction can remain unnoticed, but when a new sensitive host plant appears symptoms can be observed. Reversion disease is an example of old disease for which the causal agent has been found only during the last 15 years. Raspberry bushy dwarf virus (RBDV) is an example of an established pollen-borne virus identified in Finland in 1996 which has naturally spread to other host plants (Kokko et al. 1996).

\section{Blackcurrant reversion virus}

For the survival of an alien virus it is important that the virus has suitable host plants, wild or cultivated, in the new region and vectors to further its spread (Jones 2009). Currants were domesticated in northern Europe within the past 400-500 years, the first published description probably being that of redcurrant in a German manuscript of the early 15th century. The blackcurrant (Ribes nigrum L.) was first recorded in Britain in 17th century herbals (Simmonds 1979). Blackcurrant reversion disease was first described in the Netherlands (Ritzema Bos 
Vol. 20(2011): 29-41.

1904) and the disease was very common in Great Britain (Lees 1925). Symptomatic blackcurrants have been observed in Scandinavian countries from 1920 (Tapio 1963). Reversion disease with mild symptoms was very common in Finland, but the severe form of the disease with malformed flowers was found only in a few localities. Reverted leaves and deformed flowers were also observed among wild Ribes plants (R. alpinum L. and R. spicatum Robson) (Bremer 1983). Although Blackcurrant reversion virus (Lemmetty and Lehto 1999, Susi 2004) was isolated in Finland in 1990, the original source of a severe form of the virus was a blackcurrant breeding line from the Scottish Crop Research Institute. The plant had been grown in the experimental field of MTT Agrifood Research Finland/ Horticulture, Piikkiö, Finland since 1983 and produced malformed flowers, i.e. typical symptoms of the severe form of reversion disease, since 1987 (Lemmetty et al. 1997). It is probable that the causal agent of reversion disease, Blackcurrant reversion virus, was imported into Finland in infected plant material. However, wild Ribes species serve as host plants in which the virus can survive. In addition, Cecidophyopsis species (Bremer and Heikinheimo 1980) transmit the virus very effectively and occur in Finland (Lemmetty et al. 2001).

\section{Raspberry bushy dwarf virus}

Seed- and pollen-borne Raspberry bushy dwarf virus (RBDV) was first isolated in 1989 from raspberry (Rubus idaeus L.) breeding line ('Malling Promise' $\times$ 'Merva') $\times$ ('Malling Promise' $\times$ 'Merva') and later from cultivated raspberry (cv. Asker) in home gardens and from wild raspberries. In 1993 RBDV was isolated from new hosts of arctic bramble $(R$. arcticus L.) and its hybrid with Alaskan arctic bramble (Rubus arcticus subsp. stellatus G. Larsson) (Kokko et al. 1996).

A collection of Finnish raspberry clones was maintained for many years in MTT Agrifood Research Finland/Horticulture, Piikkiö in the open and was subjected to plant diseases and pests. During 2006-2008 the presence of RBDV was tested in clones of 42 Rubus idaeus, one Rubus plicatus Weihe \& Nees, one Rubus nessensis Hall and one Rubus pyramidalis Kaltenb. using ELISA (Loewe Biochemica, GmbH, Germany). As a result, 21\% (9/42) of the raspberry clones were found to be RBDV infected. The other three Rubus species were free of the virus. Based on the decision of the Working Group for Fruit and Berries under the National Programme for Plant Genetic Resources, the Finnish Rubus clones free of RBDV were selected for long-term conservation in the national collection. For the long term preservation and virus eradication new cryotechniques for raspberries have been introduced in Finland. The use of cryopreservation protocols ensures the preservation of the plant material in safe for plant viruses in contrast to field-maintenance (Nukari et al. 2009). A new application where cryotherapy is combined to thermotherapy has been designed for the elimination of RBDV from raspberries (Wang et al. 2008).

\section{Viroid infections of ornamentals represent a potential threat to food crops}

Viroids are the smallest known plant pathogens and are distinguishable from viruses by, for example, lack of coat protein. Potato spindle tuber disease, which is one of the most serious viroid diseases, was already known in the early 1920s in the USA. However, nothing was known about its causal agent and further characterization of viroids was not begun until the late 1960s. The damage caused by viroids in susceptible plants is largely comparable with the damage caused by viruses (Randles 2003). Like viruses, viroids can also cause asymptomatic infections in many host plants, which increases the risk of their spreading in international plant trade.

Several findings of Potato spindle tuber viroid (PSTVd) and other pospiviroids in asymptomatic ornamental plants belonging to the families Solanaceae or Gesneriaceae were made in the 


\section{AGRICULTURAL AND FOOD SCIENCE}

Lemmetty, A. et al. Emerging virus and viroid pathogen species

Netherlands in 2006 (Netherlands Plant Protection Service 2006, Verhoeven et al. 2008). They were considered alarming because many pospiviroids are very easily sap transmissible and can cause severe symptoms in food crops such as potatoes and tomatoes (Verhoeven et al. 2004). Soon after these findings the European Commission gave a decision (2007/410/EC) on measures against the introduction and spread of Potato spindle tuber viroid. This viroid is a quarantine organism listed in the phytosanitary Directive 2000/29/EC. The commission decision obliges the EU member states to conduct official surveys and testing for PSTVd.

\section{Five viroids detected in Finland}

Evira has carried out surveys for PSTVd since 2007, as laid down in the Commission Decision (2007/410/EC). Samples for laboratory analyses have been taken from marketed planting material of greenhouse-grown ornamentals and tomatoes as well as from potato nuclear stocks. PSTVd was first found in 2008. During 2008 and 2009, among the 124 ornamental plant samples studied, six plant lots were infected by this viroid (Table 1).

In connection with surveillance for PSTVd, three other pospiviroids, namely Tomato apical stunt viroid (TASVd), Tomato chlorotic dwarf viroid (TCDVd) and Chrysanthemum stunt viroid (CSVd) were detected in 11 ornamental plant lots (Table 1). None of the plants showed symptoms. Viroids were not detected in the 271 vegetable or 265 potato samples tested. All infected ornamental plants or the vegetative propagation material were transported into Finland mainly from other EU countries.

The fifth viroid to be detected in Finland was the cucumber-infecting strain of Hop stunt viroid (HSVd), the causal agent of cucumber pale fruit disease. This disease was first detected in the Netherlands in 1963 (Van Dorst and Peters 1974). After that time this viroid strain has been only very rarely found. In Finland, an HSVd outbreak was detected in summer 2009 in a cucumber greenhouse crop showing typical and severe symptoms of pale fruit disease. The origin of the infection remained a mystery. HSVd is known not to be seed transmitted, soil borne or aphid borne. It is easily transmitted mechanically (Van Dorst and Peters 1974). The infected cucumber plants were cultivated from seed at the same vegetable production site where the outbreak occurred.

\section{Conclusion}

Global trade seems to be the main reason for the introduction of the new emerging pathogens in Finland. Obviously, more virus pathogens have been transported into Finland with diverse plant material, but four new emerging viruses have been identified in greenhouse crops during the last 15 years, two of them from ornamentals and two of vegetables. PnMV, PepMV and ZYMV were associated with symptomatic plants which were observed for the first time by a grower who contacted the plant health authorities. INSV was found in symptomatic Begonia sp. by a plant inspector. PnMV has arrived occasionally with transported poinsettia cuttings and it can cause problems for growers because the virus decreases the decorative value of poinsettias. In some years the symptoms are mild and in others they are more severe. However, another emerging virus transported with plant material, INSV, can represent a substantial threat in greenhouses where both ornamentals and vegetables are cultivated, and especially in year round cultivation where some host plants are present all the time. Furthermore, F. occidentalis, a vector of INSV, occurs in Finnish greenhouses. To date all INSV infected plants have been destroyed and INSV has not become established in Finnish greenhouses.

The first PepMV infected tomato plants were observed in the area where there is a cluster of greenhouse vegetable production units. Although the survey conducted by Evira revealed that PepMV occurred in greenhouses in which tomato fruits are produced, the virus has been successfully eradicated. Continued strict hygiene measures in green- 
Vol. 20(2011): 29-41.

houses and constant monitoring have ensured that PepMV is not present in greenhouses in Finland. Four identified emerging viruses in outdoor crops, HXV in hostas, ApMV in hops and GarV-B and GarV-C in garlic seem to have become established in Finland.

International warning systems and alert lists help to draw attention to new virus and viroid pathogens occurring in plant material in international trade. Depending on the virus strain, host plant, vector and environment, the pathogen can be introduced and become established. Sometimes the imported plant materials have reached the grower before the problems have appeared. Sometimes the origin of a new virus remains unknown, such as when ZYMV appeared in a cucumber greenhouse and it was only local in occurrence. Although the virus is aphid-transmitted, a clear source of virus is still not obvious. A reduction in the range of pesticides that can be used to manage plant pests, on account of their negative effects on the environment, will make it problematical to control many vectors of virus diseases in the future.

The more surveys that can be done using more sensitive detection methods, the more new pathogens will be found. Commercially available ELISA kits make it possible to detect new viruses which earlier were not possible to identify, like Garlic viruses $B$ and $C$. Available sequence information of plant viruses and published primers for many new viruses have promoted use of nucleic acid based detection methods.

Viroids have only relatively recently been detected using molecular methods in Finland and all detected infestations have been eradicated by destroying the infected plant lots or crops and by cleaning and disinfecting the production sites. However, the results of the survey, which was admittedly not comprehensive, are alarming. It seems very likely that viroid infections occur more widely than appreciated in ornamental plants in Finnish greenhouses, garden centres, parks and home gardens. To prevent their spread to susceptible food crops, phytosanitary authorities have informed and warned vegetable growers about the risk represented by ornamental plants being cultivated together or alternately with vegetables at the same produc- tion site. It is very probable that the phytosanitary risk represented by viroids will become much more evident when more comprehensive surveillance for viroid diseases is carried out in various countries.

\section{References}

Best, R.J. 1968. Tomato spotted wilt virus. Advances in Virus Research 13: 65-146.

Bos, L.1970. Symptoms of virus diseases in plants. 2nd ed. Centre for Agricultural Publishing and Documentation. Wageningen. The Netherlands. $206 \mathrm{p}$.

Botermans, M., Verhoven, J.Th.J., Jansen, C.C.C. \& Roenhorst, J.W. 2009. First report of Tomato yellow leaf curl virus in tomato in the Netherlands. Plant Disease 93: 1073.

Bradford, F.C. \& Joley, L. 1933. Infectious variegation in the apple. Journal of Agricultural Research 46:901-908.

Brasier, C. 2005. Preventing invasive pathogens: deficiencies in the system. The Plantsman 4: 54-57.

Bremer, K. 1983. Viral diseases occurring on Ribes species in Finland. Annales Agriculturae Fenniae vol 22: 104-109.

Bremer, K. 1985. Hedelmä-ja marjakasvien taudit. Kasvinsuojeluseuran julkaisu no. 76.75 p. (In Finnish)

Bremer, K. \& Heikinheimo, O. 1980. Problems of the reversion disease of Ribes in Finland. Acta Horticulturae 95: 87-91.

Brunt, A., Crablee, K., Dallwitz, M., Gibbs, A. \& Watson, L. 1996. Viruses of Plants. Descriptions and lists from the VIDE database. Cab International. University Press. UK. 1484 p.

Carfune, E. E., Perotto, M. C. \& Conci, V.C. 2006. Effect of two Allexivirus isolates on garlic yield. Plant Disease 90: 898-904.

Chen, J., Chen, J., \& Adams, M. J. 2001. Molecular characterization of a complex mixture of viruses in garlic with mosaic symptoms in China. Archives of virology 146: 1841-1853

Chico, A.W. 1983. Poinsettia mosaic virus in British Columbia. Plant Disease 67: 427-428.

Cotillion, A.C., Girard, M. \& Ducouret, S. 2002. Complete sequence of genomic RNA of French isolate of Pepino mosaic virus. Archives of Virology 147: 2231-2238.

Crowle, D. R., Pethybridge, S. J., Leggett, G. W., Sherriff, L. J. \& Wilson, C. R. 2003. Diversity of the coat proteincoding region among llarvirus isolates infecting hop in Australia. Plant Pathology 52: 655-662.

Currier, S.\& Lockhart, B.E.L. 1996. Characterization of a potexvirus infecting Hosta spp. Plant Disease 80: 1040-1043.

Daughtrey, M.L., Jones, R.K., Moyer, J.W., Daub, M.E. \& Baker, J.R. 1997. Tospoviruses strike the greenhouse industry. INSV has become a major pathogen on flower crops. Plant Disease 81(11): 1220-1230.

de Avila, A.C., de Haan, P., Kitajima, E.W., Kormelink, R., Resede, R. de O., Goldbach, R.W. \& Peters, D. 1992. 


\section{AGRICULTURAL AND FOOD SCIENCE}

Lemmetty, A. et al. Emerging virus and viroid pathogen species

Characterization of a distinct isolate of tomato spotted wilt virus (TSWV) from Impatiens sp. in the Netherlands. Journal of Phytopathology 134: 133-151.

Desbiez, C. \& Leqoc, H. 1997. Zucchini mosaic virus. Plant pathology 46: 809-829.

Evira 2007. Toimintakertomus 2007. Elintarviketurvallisuusvirasto, kasvinsuojeluyksikkö. Dnro 2327/504/2008. (In Finnish)

Fulton, RW. \& Fulton, J.L. 1980. Characterization of a tymo-like virus common in poinsettia. Phytopathology 70: 321-324.

German, T.L., Ulman, D.E. \& Moyer, J.W. 1992. Tospoviruses: Diagnosis, molecular biology, phylogeny, and vector relationships. Annual Review of Phytopathology 30: 315-348.

Hanssen, I.M., Lapidot, M. \& Thomma, B.P.H.J. 2010 a. Emerging viral diseases of tomato crops. Molecular Plant-Microbe Interactions 23: 539-548.

Hanssen, I.M., Mumford, R., Blystad, D-R., Cortez, I., Hasiow-Jaroszewska, B., Hristova, D., Pagan, I., Pereira, A-M., Peters, J., Pospieszny, H., Ravnikar, M., Stijger, I., Tomassoli, L., Varveri, C., van der Vlugt, R. \& Nielsen, S.L. 2010 b. Seed transmission of Pepino mosaic virus in tomato. European Journal of Plant Pathology 126: $145-152$.

Jones, D.R. 2003. Plant viruses transmitted by whiteflies. European Journal of Plant Pathology 109: 195-219.

Jones, D.R. 2005. Plant viruses transmitted by thrips. European Journal of Plant Pathology 113: 119-157.

Jones, R.A.C. 2009. Plant virus emergence and evolution: Origins, new encounter scenarios, factors driving emergence, effects of changing world conditions, and prospects for control. Virus Research 141: 113-130.

Jones, R.A.C., Koenig, R. \& Lesemann, D.-E.1980. Pepino mosaic virus, a new potexvirus from pepino (Solanum muricatum). Annals of Applied Biology 94: 61-68.

Kang, S.G., Bong, J.K., Eun, T.L \& Moo, U.C. 2007. Allexivirus transmitted by eriophyid mites in garlic plants. Journal of Microbiology and Biotechnology 17: 18331840.

Koenig, R. \& Lesemann, D-E. 1980. Two isometric viruses in poinsettias. Plant Disease 64: 782-784.

Kokko, H., Lemmetty, A., Haimi, P. \& Kärenlampi, S. 1996. New host for Raspberry bushy dwarf virus: arctic bramble (Rubus arcticus). European Journal of Plant Pathology 102: 713-717.

Koo, B. J., Kang, S-G. \& Moo U. C. 2002. Survey of garlic disease and phylogenetic characterization of garlic viruses of the genus Allexivirus isolated in Korea. Plant Pathology 18: 237-243.

KTTK 2002. Toimintakertomus 2002. Kasvintuotannon tarkastuskeskus, kasvintarkastus. Dnro 3/023/2003. (In Finnish)

KTTK 2003. Toimintakertomus 2003. Kasvintuotannon tarkastuskeskus, kasvintarkastus. Dnro 3/023/2004. (In Finnish)

KTTK 2004. Toimintakertomus 2004. Kasvintuotannon tarkastuskeskus, kasvintarkastus. Dnro 3/406/2005. (In Finnish)

KTTK 2005. Toimintakertomus 2005. Kasvintuotannon tarkastuskeskus, kasvintarkastus. Dnro 1/023/2006. (In Finnish)

Larsson, O. \& Lokonen, P. 1984. Taimitarhaviljelymme vaiheita. Taimistoviljelijät ry. 248 p. (In Finnish).

Law, M.D.\& Moyer, J.W. 1990. A tomato spotted wilt-like virus with a serologically distinct $\mathrm{N}$ protein. Journal of General Virology 71: 933-938.

Lees, A.H. 1925. Reversion disease of black currants: means of infection. Annals of Applied Biology 12: 199210.

Lemmetty, A., Latvala, S., Jones, A.T., Susi, P., McGavin, W.J. \& Lehto, K. 1997. Purification and properties of a new virus from blackcurrant, its affinities with nepoviruses and its close association with blackcurrant reversion disease. Phytopathology 87: 404-413.

Lemmetty, A. \& Lehto, K. 1999. Successful back-inoculation confirms the role of black currant reversion associated virus as the causal agent of reversion disease. European Journal of Plant Pathology 105: 297-301.

Lemmetty, A. \& Lindqvist, I. 1993. Thrips tabaci (Lind.) (Thysanoptera, Thripidae) another vector for Tomato spotted wilt virus in Finland. Agricultural Science in Finland 2: 189-194.

Lemmetty, A., Tikkanen, M., Tuovinen, T. \& Lehto, K. 2001. Identification of different Cecidophyopsis mites on Ribes in Finland. Acta Horticulturae 656: 115-118.

Liro, J.I. \& Roivanen, H. 1951. Suomen eläimet, Animalia Fennica 6. Äkämäpunkit, eriophyidae. WSOY, Turku. 281 p. (In Finnish).

Lisa, V., Boccardo, G., D’Agostino, G., Dellavalle, G. \& D'Aquilio, M. 1981. Characterization of a potyvirus that causes Zucchini yellow mosaic. Phytopathology 71: 667-672.

Lopez, M.M., Llop, P., Olmos, A., Marco-Noales, E., Cambra, M. \& Bertolini, E. 2008. Are molecular tools solving the challenges posed by detection of plant pathogenic bacteria and viruses? Current Issues in Molecular Biology 11:13-46.

Menzel, W., Jelkmann, W. \& Maiss, E. 2002. Detection of four apple viruses by multiplex RT-PCR assay with coamplification of plant mRNA as internal control. Journal of Virological Methods 99: 81-92.

Moriones, E., Aramburu, J., Riudavets, J., Arno, J. \& Lavina, A.1998. Effect of plant age at time of infection by tomato spotted wilt tospovirus on the yield of fieldgrown tomato. European Journal of Plant Pathology 104: 295-300.

Moriones, E. \& Navas-Castello, J. 2000. Tomato yellow leaf curl virus and emerging virus complex causing epidemics worldwide. Virus Research 71: 123-134.

Mumford, R., Boonham, N., Tomlinson, J. \& Barker, I. 2006. Advances in molecular phytodiagnostics - new solutions for old problems. European Journal of Plant Pathology 116: 1-19.

Mumford, R.A. \& Jones, R.A.C. 2005. Pepino mosaic virus. AAB Descriptions of Plant Viruses, No. 411.

Mumford, R.A. \& Metcalfe, E.J. 2001. The partial sequencing of the genomic RNA of a UK isolate of Pepino mosaic virus and the comparison of the coat protein sequence with other isolates from Europe and Peru. Archives of Virology 146: 2455-2460.

Netherlands Plant Protection Service 2006. Potato spindle tuber viroid (PSTVd) on Solanum jasminoides and Brugmansia spp. ornamental plants. Pest Report. 3 p.

Niemi, J. \& Ahlstedt, J. (eds.) 2009. Finnish Agriculture and Rural Industries 2009. MTT Economics Research. Pub- 
Vol. 20(2011): 29-41.

lications: 109a, $96 \mathrm{p}$.

Nukari, A., Uosukainen, M., Rokka, V.-M., Antonius, K., Wang, Q.C. \& Valkonen, J.P.T. 2009. Review article. Cryopreservation techniques and their application in vegetatively propagated crop plants in Finland. Agricultural and Food Science 18:117-128.

Okuda, M., Fuji, S., Okuda, S., Sako, K. \& Iwanami, T. 2010. Evaluation of the potential of thirty two weed species as infection sources of Impatiens necrotic spot virus. Journal of Plant Pathology 92: 357-361.

Paludan, N. \& Begtrup, J. 1986. Inactivation of poinsettia mosaic virus and cryptic virus in Euphorbia pulcherrima using heat treated mini-cuttings and meristem-tip culture. Tidsskrift for Planteavl 90: 283-290.

Perotto, M. C., Cafrune, E. E. \& Conci, V. C. 2010. The effect of additional viral infections on garlic plants initially infected with Allexiviruses. European Journal of Plant Pathology 126: 489-495.

Pethybridge, S. J, Barbara, D. J., Eastwell, K. C. \& Wilson, C. R. 2008. Viruses and viroids infecting hop: significance, epidemiology and management. Plant Disease 92: 324-338.

Pethybridge, S. J., Wilson, C. R., Hay, F. S., Leggett, G. W. \& Sherriff, L. J. 2002a. Mechanical transmission of Apple mosaic virus in Australian hop (Humulus lupulus) gardens. Annals of Applied Biology 141: 77-85.

Pethybridge, S. J., Wilson, C. R., Hay, F. S., Leggett, G. W. \& Sherriff, L. J. 2002b. Effect on viruses on agronomic and brewing characteristics of four hop (Humulus lupulus) cultivars in Australia. Annals of Applied Biology 140: 97-105.

Rainio, A.J. 1941. Untersuchungen uber Cucumis-Virus1, Ertreger der Kräuselkrankheit auf Gurkenpflanzen. Publications of the Finnish State Agricultural Research Board No. 109. 24 p.

Randles, J.W. 2003. Economic impact of viroid diseases. In: Hadidi, A., Flores, R., Randles, J. W. \& Semancik, J. S. (eds) Viroids. p. 3-11.

Ritzema Bos, G. 1904. Eenige misvormingen of monstrositeiten. ( Some malformations and monstrosities). Tijdschrift over Plantenziekten 10: 135-144.

Schrijnwerkers, C.C.F.M., Huijberts, N. \& Bos, L. 1991. Zucchini yellow mosaic virus; two outbreaks in the Netherlands and seed transmissibility. Netherlands Journal of Plant Pathology 97: 187-191.

Shipp J.L.,Buitenhuis, R., Stobbs, L., Wang, K., Kim, W.S. \& Ferguson, G. 2008. Vectoring of Pepino mosaic virus by bumble-bees in tomato greenhouses. Annals of Applied Biology 153: 149-155.

Simmonds, N.W. (ed.) Evolution of crop plants. Reprinted 1979. London. Currants. p.339.

Simmons, H.E., Holmes, E.C. \& Stephenson, A.G. 2008. Rapid evolutionary dynamics of zucchini yellow mosa- ic virus. Journal of General Virology 89: 1081-1085.

Song, S. I., Song, J. T., Chang, M. U., Lee, J. S. \& Choi, Y. D. 1997. Identification of one of major viruses garlic plants, garlic virus X. Molecules and cells 7: 705-709.

Sumi, S., Matsumi, T. \& Tsuneyoshi, T. 1999. Complete nucleotide sequences of garlic viruses $A$ and $C$, members of the newly ratified genus Allexivirus. Archives of virology 144: 1819-1826.

Sumi, S., Tsuneyoshi, T. \& Furutani, H. 1993. Novel rodshaped viruses isolated from garlic, Allium sativum, possessing a unique genome organization. Journal of General Virology 74: 1879-1885.

Susi, P. 2004. Black currant reversion virus, a mite-transmitted nepovirus. Molecular Plant Pathology 5(3): 167173.

Tapio, E. 1963. Virus diseases on berries. Maatalous ja koetoiminta 17: 242-251. (In Finnish)

Tapio, E., Bremer, K. \& Valkonen, J. 1997. Viruses and their significance in agricultural and horticultural crops in Finland. Agricultural and Food Science in Finland. vol. 6: 323-336.

van der Vlugt, R.A.A. 2009. Pepino mosaic virus. Hellenic Plant Protection Journal 2: 47-56.

van der Vlugt, R.A.A., Stijger, C.C.M.M., Verhoeven, J.Th.J., Verhoeven, J. \& Lesemann, D.E. 2000. First report of Pepino mosaic virus on tomato. Plant Disease 84(1), 103.

Van Dorst, H.J.M. \& Peters, D. 1974. Some biological observations on pale fruit, a viroid-incited disease of cucumber. Netherlands Journal of Plant Pathology 80: 85-96.

Verhoeven, J.Th.J., Jansen, C.C.C. \& Roenhorst, J.W. 2008. First report of pospiviroids infecting ornamentals in the Netherlands: Citrus exocortis viroid in Verbena sp., Potato spindle tuber viroid in Brugmansia suaveolens and Solanun jasminoides, and Tomato apical stunt viroid in Cestrum sp. Plant Pathology 57: 399.

Verhoeven, J.Th.J., Jansen, C.C.C., Willemen, T.M., Kox, L.F.F., Owens, R.A. \& Roenhorst, J.W. 2004. Natural infections of tomato by Citrus exocortis viroid, Columnea latent viroid, Potato spindle tuber viroid and Tomato chlorotic dwarf viroid. European Journal of Plant Pathology 110: 823-831.

Verhoeven, J.Th.J., van der Vlugt, R.A.A. \& Roenhorst, J.W. 2003. High similarity between tomato isolates of Pepino mosaic virus suggests a common origin. European Journal of Plant Pathology 109: 419-425.

Wang, Q.C., Cuellar, W., Rajamäki, M.L., Hirata, Y. \&Valkonen, J.P.T. 2008. Combined thermotherapy and cryotherapy for virus eradication: relation of virus distribution, subcellular changes, cell survival and viral RNA degradation in shoot tips to efficient production of virus free plants. Molecular Plant Pathology 9: 237-250. 